\title{
Bakteeritaudinaiheuttajien tarkennettu tunnistus mikrosirudiagnostiikalla
}

\author{
Marja Aittamaa ${ }^{1}$, Petri Auvinen ${ }^{2}$, Katja Hinderink ${ }^{3}$, Katri Kiviniemi ${ }^{3}$, Hannu Korkeala ${ }^{3}$, Outi \\ Leppäranta ${ }^{4}$, Miia Lindström ${ }^{3}$, Mirjami Mattila ${ }^{3}$, Vesa Myllys ${ }^{4}$, Suvi Nykäsenoja ${ }^{4}$, Minna Pirhonen ${ }^{1}$, \\ Leila Rantala ${ }^{4}$, Panu Somervuo ${ }^{1,2,3,4}$, Henna Söderholm ${ }^{3}$, ja Jari Valkonen ${ }^{1}$ \\ ${ }^{1}$ Soveltavan biologian laitos, PL 27, 00014 Helsingin yliopisto \\ ${ }^{2}$ Biotekniikan instituutti, PL 56, 00014 Helsingin yliopisto \\ ${ }^{3}$ Elintarvike- ja ympäristöhygienian laitos, PL 66, 00014 Helsingin yliopisto \\ ${ }^{4}$ Mikrobiologian tutkimusyksikkö, Elintarviketurvallisuusvirasto Evira, Mustialankatu 3, 00790 \\ Helsinki
}

Monien maa- ja elintarviketalouden kannalta merkittävien bakteeritaudinaiheuttajien luotettava tunnistus on ongelmallista. Näihin lukeutuvat perunan uusi, maa- ja siemenlevintäinen taudinaiheuttaja pohjanrupibakteeri (Streptomyces turgidiscabies), voimakasta hermomyrkkyä tuottava, vakavia ruokamyrkytyksiä ja halvauksia aiheuttava, elintarvikkeissa kulkeutuva Clostridium botulinum, sekä ihmisille tautia aiheuttavat enterohemorragiset Escherichia coli -bakteerit (EHEC-bakteerit; zoonoositaudinaiheuttajat), joiden tärkeimpänä lähteenä pidetään nautoja. Sopivan diagnostiikan puuttuessa edellä mainittuja, tauteja aiheuttavia bakteerikantoja ja -lajeja ei voida erottaa haitattomista, joita osa näytteiden mikrobeista edustaa. DNA-mikrosirut edustavat uutta diagnostista lähestymistapaa. Mikrosirulla tapahtuva tunnistus antaa poikkeuksellisen laajat mahdollisuudet mikrobin kuvailun yksityiskohtaisuudelle. Siten esim. taudinaiheuttamiskykyyn tarvittavien geenien yhdistelmää tai taudin-aiheuttajalle ominaisia, minimaalisia geneettisiä eroja voidaan hyödyntää kokonaisuutena tunnistuksessa.

Tämän hankkeen keskeisenä tavoitteena oli DNA-mikrosirutekniikan käyttöönottaminen diagnostiikassa. Koska menetelmä oli hankkeen alkaessa kansainvälisestikin ottaen uusi ja vasta kehitteillä, hankkeessa tukeuduttiin neljän tutkimuslaboratorion yhteistyöhön mahdollisimman nopean etenemisen varmistamiseksi. Soveltavan biologian laitoksen kasvipatologian laboratorio (Helsingin yliopisto, HY) koordinoi hanketta ja keskittyi perunan bakteeritaudinaiheuttajiin. Elintarvike- ja ympäristöhygienian laitos (HY) tutki ruokamyrkytysbakteereja. Elintarviketurvallisuusvirasto Eviran mikrobiologian tutkimusyksikkö tutki puolestaan EHEC-bakteereja. Mikrosirukokeet tehtiin Biotekniikan instituutin (HY) mikrosirulaboratoriossa, joka toimi teknologisena asiantuntijana. Hankkeeseen palkattiin yhteinen bioinformaatikko kehittämään tulosten käsittelyssä tarvittavia menetelmiä. Tutkimuksen lopullisena tavoitteena oli edistää elintarviketurvallisuutta, tuotantoeläinten terveyttä, elintarvike-tuotannossa käytettävien materiaalien hygieniaa sekä perunan kasvinsuojelua.

Tutkimuksissa edettiin alun teknisten vaikeuksien jälkeen nopeasti, kun uusi mikrosirujen valmistusteknologia tuli käyttöön. Hankkeen tulokset edustavat tieteellisesti uudenaikaista lähestymistapaa bakteerien tyypittämiseen. Mikrosiruteknologian avulla oli mahdollista erotella kaikki perunalla merkittävät, Suomessa tavattavat bakteeritaudinaiheuttajat. Mikrosiruanalyysit paljastivat joukon $C$. botulinum:in geenejä, joiden perusteella bakteerikannat voitiin jakaa proteolyyttisten ominaisuuksien mukaisesti kahteen ryhmään ja kehittää niiden tunnistukseen nopea PCR-testi. Samalla periaatteella voitiin erotella tunnetusti patogeenisiä ja mahdollisesti patogeenisiä E. coli -kantoja. Tulokset veivät eteenpäin taudinaiheuttamiskykyyn liittyvien monimutkaisten ilmiöiden tutkimusta ja tuottivat diagnostiikassa sovelluskelpoisia tuloksia.

Asiasanat: mikrosiru, diagnostiikka, bakteeri, taudinaiheuttaja, elintarviketurvallisuus, kasvinsuojelu, zoonoosi, hygienia 


\section{Johdanto}

Monien maa- ja elintarviketalouden kannalta merkittävien bakteeritaudinaiheuttajien luotettava tunnistus on ongelmallista. Perunaa vaivaa lukuisa joukko märkä-, tyvi- ja rengasmätää tai perunarupea aiheuttavia bakteereja, joita esiintyy lähes kaikilla perunantuotantoalueilla (Lehtonen ym. 2004; Van der Wolf \& De Boer 2007). Näihin lukeutuu myös verrattain uusi, maa- ja siemenlevintäinen perunan taudinaiheuttaja pohjanrupibakteeri (Streptomyces turgidiscabies) (Lehtonen ym. 2004). Elintarvikkeiden pilaantumista voi aiheuttaa viileissäkin säilytysoloissa voimakasta hermomyrkkyä tuottava, vakavia ruokamyrkytyksiä ja halvauksia aiheuttava Clostridium botulinum (Lindström \& Korkeala 2006; Sebaihia ym. 2007). Ihmisille tautia aiheuttavia Escherichia coli -kantoja (EHECbakteerit) voi piillä nautakarjassa, josta ne saattavat siirtyä ihmisiin esimerkiksi kontaminoituneen juomaveden tai ruuan välityksellä aiheuttaen vakavia oireita (Karch ym. 1999; Lahti ym. 2002; O’Connell 2007). Sopivan diagnostiikan puuttuessa tauteja aiheuttavia bakteerikantoja ja -lajeja on vaikeaa erottaa näytteissä esiintyvistä haitattomista bakteerilajeista ja -kannoista. DNA-mikrosirut edustavat uutta diagnostista lähestymistapaa. Mikrosirulla tapahtuva tunnistus mahdollistaa mikrobin kuvailun erittäin yksityiskohtaisesti. Siten esim. taudin-aiheuttamiskykyyn tarvittavien geenien yhdistelmää tai taudinaiheuttajalle ominaisia, minimaalisia geneettisiä eroja voidaan hyödyntää kokonaisuutena. Tautia aiheuttavien bakteerikantojen tunnistus tällä tarkkuudella on uusi, mikrosirujen tuoma mahdollisuus.

Tämän hankkeen alkuperäisenä tavoitteena oli DNA-mikrosirutekniikan käyttöönottaminen. Hanketta tuki merkittävästi v. 2002 alkanut ja v. 2007 päättynyt Euroopan laajuinen COST853-hanke (www.cost853.org), johon osallistui 21 maata ja jonka tavoitteena oli mikrosirudiagnostiikan kehittäminen maatalouden tarpeisiin. Koska menetelmä oli hankkeen alkaessa kansainvälisestikin ottaen uusi ja vasta kehitteillä, hankkeessa tukeuduttiin neljän Viikissä sijaitsevan tutkimuslaboratorion yhteistyöhön mahdollisimman nopean etenemisen varmistamiseksi. Soveltavan biologian laitoksen kasvipatologian laboratorio koordinoi hanketta ja keskittyi perunan bakteeritaudin-aiheuttajiin. Elintarvike- ja ympäristöhygienian laitos tutki ruokamyrkytysbakteereja. Elintarviketurvallisuusvirasto Eviran mikrobiologian yksikkö keskittyi EHEC-bakteereihin. Mikrosirukokeet tehtiin Biotekniikan instituutin mikrosirulaboratoriossa, joka toimi mikrosiruteknologian asiantuntijana. Hankkeeseen palkattiin yhteinen bioinformaatikko kehittämään tulosten käsittelyssä tarvittavia menetelmiä. Tässä raportissa esitellään hankkeen ensimmäisiä. sovellettavia tuloksia. Tutkimus jatkuu ja sen lopullisena tavoitteena on kehittää mikrosiruteknologiaan perustuva tunnistusmenetelmä edellä mainituille kolmelle bakteeritaudinaiheuttajalle edistämään elintarvike-turvallisuutta, tuotantoeläinten terveyttä, elintarviketuotannossa käytettävien materiaalien hygieniaa sekä perunan kasvinsuojelua.

\section{Aineisto ja menetelmät}

Perunan bakteeritaudinaiheuttajien tunnistukseen suunniteltiin synteettisiin koettimiin perustuva mikrosiru. Koettimien suunnittelussa hyödynnettiin koko bakteerigenomin sekvenssi niistä lajeista, joista se oli tietokannoista saatavilla (Clavibacter michiganensis subsp. sepedonicus, Pectobacterium atrosepticum ja Streptomyces scabies), tai muuta useimmista lajeista saatavilla olevaa sekvenssitietoa. Koettimet suunniteltiin OligoArray 2.0-ohjelman avulla (Rouillard ym. 2003). Periaatteena oli, että kohdespesifi osa koetinta oli 40 emästä pitkä ja että kaikkien koetinten sitoutuminen kohteeseensa tapahtuisi suurin piirtein yhtä tehokkaasti samassa lämpötilassa (ts. koettimen ja sen vastinjuosteen erkanemislämpötila, $\mathrm{Tm}=82-90^{\circ} \mathrm{C}$ ), jolloin sirun hybridisointi- ja pesuolosuhteilla voitaisiin ehkäistä mahdollisimman tehokkaasti epäspesifin hybridisaation aiheuttamat taustasignaalit. Sirut teetettiin Agilent-yhtiössä. Jokaisella sirulla oli kahdeksan samanlaista 9676 koettimen ryhmää, joista jokainen voitiin käyttää eri näytteen tutkimiseen.

EHEC-bakteerien tutkimukseen käytettiin kaupallisesti saatavissa olevaa OciChip E. coli O157 -sirua (Ocimum Biosolutions), jolla on 6176 kpl 50 emäksen mittaista, kolmen E. coli-kannan genomisekvenssin mukaan suunniteltua koetinta.

C. botulinum-siru oli valmistettu Englannissa (Institute of Food Research, Norwich) osana yhteistyöprojektia, johon Elintarvike- ja ympäristöhygienian laitos osallistui. Sirulla oli 4224 koetinta bakteerin kromosomin ja plasmidin geeneille. 
Bakteerien puhdasviljelmistä eristettiin DNA:ta, joka analysoitiin mikrosiruilla sirujen valmistajien ohjeiden mukaisesti. Näyte-DNA leimattiin fluoresoivilla Cy3- tai Cy5-väriaineilla. Kaksi eri leimalla merkittyä näytettä analysoitiin samalla sirulla, jolloin näytteiden antamia signaalitasoja voitiin verrata koetinkohtaisesti. Koetinten antamat signaalit mitattiin ja tulokset analysoitiin GenePix-yhtiön laitteilla ja ohjelmistoilla.

\section{Tulokset ja tulosten tarkastelu}

\section{Perunan bakteeritaudinaiheuttajien tunnistus}

Alustava mikrosirutesti kehitettiin tunnistamaan tärkeimmät Suomessa esiintyvät perunan bakteeritaudinaiheuttajat. Niitä ovat perunarupea aiheuttavat Streptomyces turgidiscabies (Stu) ja S. scabies (Ssc), tyvi- ja märkämätää aiheuttavat Pectobacter carotovora (Pca), Pectobacter atrosepticum (Pat) sekä Dickeya-lajit, jotka kaikki kuuluivat aiemmin Erwinia-sukuun, sekä vaaleaa rengasmätää aiheuttava Clavibacter michiganensis sp. sepedonicus (Cms). Koko genomisekvenssin saatavuus kolmesta lajista (Cms, Pat, Sts) mahdollisti koettimien suunnittelun lajin geeneille siten, että koettimet olivat sekä geeni- että lajispesifejä. Koettimia oli jokaiselle Pat-lajin geenille, 50 \%:lle Ssc:n geenejä sekä n. 30 \%:lle Cms:n geenejä. Lisäksi koettimia oli Stu:n genomin 'patogeenisuussaarekkeen' geeneille ja niiden välialueille (Kers ym. 2005), Pectobacterium- ja Dickeya-kantojen taudinaiheuttamiskykyyn liittyville nip-geeneille (Mattinen ym. 2004) sekä bakteerien ribosomaalista RNA:ta koodaavien geenien (16S-23S) välialueelle. Yhteensä koettimia oli tärkeimmille lajeille seuraavat määrät: Pat $4457 \mathrm{kpl}$, Ssc $3908 \mathrm{kpl}$, Cms $1005 \mathrm{kpl}$ ja Stu $230 \mathrm{kpl}$. Nämä lajit voitiin helposti erottaa toisistaan mikrosirutestin avulla (Kuva 1). Myös saman suvun lähisukuiset lajit erottuivat toisistaan 9676 koettimen antaman signaalisormenjäljen perusteella. Jokaisesta lajista käytettävissä olleet lajispesifit koettimet mahdollistivat tutkittavan kannan lajinmäärityksen.
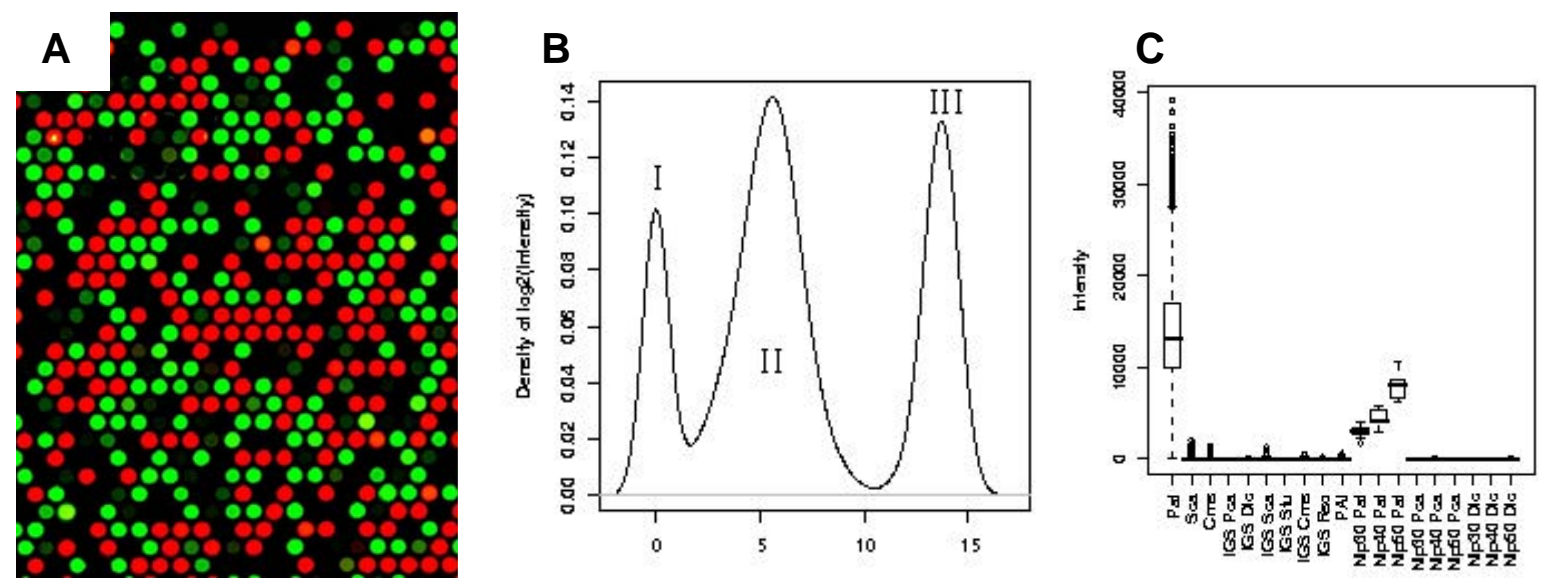

Kuva 1. A, Pieni alue perunabakteerimikrosirusta (n. 600 koetinta 9676:sta). Koettimia on tasaisesti koko alueella. Ne tunnistavat neljän bakteerisuvun lajeja. Tässä testissä S. scabies-lajin DNA-näyte on leimattu Cy3väriaineella (esitetty vihreänä) ja Pectobacterium atrosepticum-lajin näyte Cy5-värillä (punainen), minkä jälkeen näytteet on yhdistetty ja testattu samalla sirulla. Koetinten antama signaali on enimmäkseen vahva tai sitä ei ole lainkaan (musta tausta). Vain osa koettimista antaa heikkoa mutta havaittavaa, epäspesifiä signaalia. Tulos osoittaa, että suurin osa koettimista tunnistaa vain oman kohdelajinsa. B, Sirun koettimien jakautuminen kolmeen ryhmään signaaliensa voimakkuuden mukaan, kun näytteenä oli P. atrosepticum-lajin DNA: III, vahva signaali; II, heikko signaali; I, ei signaalia. Lajien erotteluun käytettiin vain vahvoja signaaleja antavia koettimia, mutta muutkin koettimet olivat hyödyllisiä, koska niiden heikompiin signaaleihin verraten voitiin määritellä vahvojen signaalien (koetinten) ryhmä. C, $P$. atrosepticum-lajin testauksessa vahvimmat (spesifimmät) signaalit saatiin koettimilla, jotka oli suunniteltu tämän lajin sadoille eri geeneille (koetinryhmä Pat). Myös taudinaiheuttamiskykyyn kytkeytyvälle nip-geenille sunnitellut erimittaiset koettimet osoittautuivat varsin lajikohtaisiksi. Kuvissa B ja C on esitetty signaalivoimakkuuksien logaritmiset $\left(\lg _{2}\right)$ arvot. Kaikki näytteet koostuivat saman lajin usean kannan DNA:n yhdistelmästä. 


\section{Clostridium botulinum-lajin roturyhmien erot}

Genomivertailussa selvitettiin 54 proteolyyttisen (ryhmä I) ja 6 ei-proteolyyttisen (ryhmä II) $C$. botulinum -kannan genomisia eroja hybridisoimalla niiden leimattua DNA:ta ryhmän I kannan (ATCC 3502) 3500 geeniin perustuvalle mikrosirulle. Tulokset analysoitiin bioinformatiikan keinoin kantojen välisten geenierojen määrittämiseksi. Ryhmien I ja II C. botulinum -kannat erosivat genomisilta ominaisuuksiltaan toisistaan huomattavasti: vain n. 800 (23\%) geeniä oli yhteisiä molemmille ryhmille. Ryhmiä I ja II yksiselitteisesti erottavien geenialueiden perusteella voitiin kehittää PCRmenetelmä ryhmien erottamiseksi toisistaan (Dahlsten ym. 2006). Tämä oli C. botulinum diagnostiikassa suuri edistysaskel, sillä aiemmin erottelu on perustunut hitaaseen ja tulkinnanvaraiseen viljelymenetelmään. PCR-menetelmä antaa yksiselitteisen tuloksen kannan metabolisesta ryhmästä neljässä tunnissa. Metabolisen ryhmän selvittäminen on tärkeää mm. botulismitapausten epidemiologisessa selvitystyössä. Esimerkki osoittaa mikrosirutekniikan ja sen tuloksia tukevien menetelmien ylivertaisuuden myös käytännön diagnostiikan näkökulmasta.

Verrattaessa ryhmän I tyypin B kantoja toisiinsa mikrosirutekniikalla havaittiin kaksi ryhmää. Yhteen ryhmittyvät kannat olivat todennäköisesti hyvin samankaltaisia, mutta ryhmät erosivat toisistaan n. 145 geenin osalta. Näiden geenien joukossa oli mm. arseeniresistenssiä koodaava toiminnallinen yksikkö sekä kadmiumkestävyyteen liittyvä geeni. Ryhmien erot arseeni- ja kadmiumkestävyydessä voitiin osoittaa laboratoriotestein (Lindström ym. 2007). DNA-mikrosirutekniikan tulosten luotettavuutta tukivat myös PCR-testit.

Optimilämpötilassa $\left(37^{\circ} \mathrm{C}\right)$ kasvatetun ja ns. kylmäshokin $\left(15^{\circ} \mathrm{C}\right)$ kokeneen C. botulinum ATCC 3502 -kannan kasvustojen geeniekspressioprofiileja verrattiin toisiinsa. Korkeammassa lämpötilassa voimakkaimmin ilmentyvistä geeneistä valtaosa kuului bakteriofaagiproteiinien tuotantoa ohjaaviin geeniryhmiin. Kylmäshokin kokeneella kasvustolla taas voimakkaimmin ilmentyivät erilaiset säätelygeenit, solun aktiiviseen aineenvaihduntaan liittyvät geenit sekä tunnetut kylmäshokkigeenit. Huomionarvoista on, että botulinumneurotoksiinin tuotantoa säätelevä botR aktivoitui pian kylmäshokin jälkeen, mikä osoittaa, että kylmäshokilla ei välttämättä ole toksiinintuotantoa merkittävästi estävää vaikutusta. Kvantitatiivinen RT-PCR-menetelmä osoitti geeniekspressiokokeen tulokset luotettaviksi.

Diagnostisen, kylmänsietogeeneihin perustuvan mikrosirun avulla voitaisiin tunnistaa erityisesti kylmää sietävät eli elintarviketurvallisuuden näkökulmasta haitallisimmat C. botulinum -kannat. Edellytyksenä on kuitenkin vielä yksityiskohtaisempi tieto geenien yhteistoiminnasta ja tehtävistä kokonaisuudessaan. Hankkeen aikana tässä ja muissa tutkimuksissa kertynyt aineisto osoittaa, että kylmänsieto on erittäin monitahoinen ilmiö. Sitä on syytä jatkossa selvittää erilaisilla koeasetelmilla. DNA-mikrosirutekniikan lisäksi tarvitaan myös muita, geenien toimintaa selvittäviä tutkimusmenetelmiä esim. proteiini- ja metaboliatasoilla.

\section{EHEC-bakteerikantojen ryhmittely mikrosirutestin avulla}

Taudinaiheuttamiskyvyltään ja geenikoostumukseltaan erilaisia E. coli-kantoja verrattiin mikrosirujen avulla pyrkien tunnistamaan tautia aiheuttavat EHEC-kannat mikrosirusignaalien perusteella. Tutkimuksessa oli mukana mm. nautojen ulosteista eristettyjä bakteerikantoja sekä kotimaisia ja ulkomaisia, ihmisten tautitapauksiin yhdistettyjä bakteerikantoja. EHEC-bakteereista merkittävä osa kuuluu seroryhmään O157, joita tutkituista 21 E. coli -kannasta oli 19.

Ulkomaisten kantojen havaittiin eroavan geneettisesti kotimaisista kannoista, pääasiassa neljän profaagin geenien osalta. Niin sanotut ei-patogeeniset E. coli -kannat erottuivat analyyseissä selkeästi omaksi ryhmäkseen: niiltä puuttuu EHEC-kannoille spesifisiä profaageja, yhteensä noin sata geeniä.

Analysoimalla tuloksia bioinformatiikan menetelmin löydettiin joukko geenejä, jotka parhaiten erottelivat tunnetusti patogeenisiä ja mahdollisesti patogeenisiä E. coli -kantoja. Nykymääritelmän mukaan patogeenisiksi luettavien kantojen mikrosiruprofiileja verrattiin ihmisten tautitapauksiin yhdistettyihin eli varmasti patogeenisiin kantoihin ja toisaalta mahdollisesti patogeenisiin kantoihin. Tulokset vaihtelivat hieman riippuen siitä, kuinka monen geenin osalta vertailuja tehtiin. 
Tutkimuksessa tehtiin mikrosiruihin perustuvan EHEC-bakteerien tunnistustestin tuotekehityksen kannalta välttämätöntä perustason tutkimusta patogeenisten ja ei-patogeenisten $E$. coli -kantojen geneettisten eroavaisuuksien kartoittamiseksi. Mikrosiruprofiileihin perustuva luotettava tautia aiheuttavien ja haitattomien bakteerikantojen erottaminen vaatii kuitenkin vielä lisätutkimuksia.

\section{Johtopäätökset}

Mikrosiruanalyysit tuottivat runsaasti uutta tietoa tutkimuksen kohteena olleiden bakteerilajien geneettisistä eroista sekä lajinsisäisistä eroista bakteerikantojen välillä. Tulokset olivat lupaavia ottaen huomioon hankkeen päätavoite, joka on patogeenisten ja tautia aiheuttamattomien bakteerikantojen erottaminen toisistaan. Hankkeen alkuvaiheessa tutkimusta hidastivat teknisesti huonolaatuiset mikrosirut, mutta siirtyminen uudenlaiseen sirujen valmistusstrategiaan viimeisimmän vuoden aikana poisti ongelman. Tulosten laatu osoittautui erinomaiseksi, kun käytettiin sekvenssitietojen perusteella suunniteltuja, synteettisiin oligonukleotideihin perustuvia siruja. Näillä siruilla koettimet syntetisoidaan suoraan mikrosirulle. Lisäksi sirujen valmistuksessa voidaan hyödyntää kohdemikrobien genomisekvenssiä koskeva tieto täysimääräisesti. Kokonaisten genomien sekvensointi kiihtyy kaiken aikaa entistä nopeampien ja kustannustehokkaampien menetelmien ansiosta. Siten sirujen valmistaminen rajoittuu tutkimusryhmän näkökulmasta bioinformaatikon työpanokseen. Samalla sirulla voidaan analysoida jopa 32 näytettä kahta eri leimausväriä käyttäen. Siruja voidaan tilata yksitellen. Kaiken kaikkiaan mikrosiruanalyysien kulut ovat nopeasti laskeneet samalle tasolle muiden perusanalyysien, kuten vaikkapa reaaliaikaisen PCR-analyysin kanssa. Erona on kuitenkin tuhansien geneettisten parametrien samanaikainen mittaaminen näytteestä, mitä muut perusmenetelmät kuin mikrosirut eivät mahdollista.

\section{Kiitokset}

Esitämme parhaat kiitoksemme hankkeen ohjausryhmätyöskentelyyn osallistuneille sekä hankkeen rahoittajille (Maa- ja metsätalousministeriö, TEKES, Mobidiag Oy ja Ani Biotech Oy).

\section{Kirjallisuus}

Dahlsten, E., Lindström, M., Somervuo, P. \& Korkeala, H. 2006. PCR assay for differentiating between group I (proteolytic) and group II (nonproteolytic) strains of Clostridium botulinum. Interagency Botulism Research Coordinating Committee Meeting, Silver Spring, Maryland, USA, p. 77.

Karch, H., Schubert, S., Zhang, D., Zhang, W., Schmidt, H., Ölschläger, T. \& Hacker, J. 1999. A genomic island, termed high-pathogenicity island, is present in certain non-O157 Shiga toxin-producing Escherichia coli clonal lineages. Infection and Immunity 67: 5994-6001.

Kers, J.A., Cameron, C.D., Joshi, M.V., Burkhalid, B.A., Morello, J.E., Wach, M.J., Gibson, D.M. \& Loria, R. 2005. A large, mobile pathogenicity island confers plant pathogenicity on Streptomyces species. Mol. Microbiol. 55: 1025-1033.

Lahti, E., Eklund, M., Ruutu, P., Siitonen, A., Rantala, L., Nuorti, P. \& Honkanen-Buzalski, T. 2002. Use of phenotyping and genotyping to verify transmission of Escherichia coli O157: H7 from dairy farms. Eur. J. Clinical Microbiol. 21: 189-195.

Lehtonen, M.J., Rantala, H., Kreuze, J.F., Bång, H., Kuisma, L., Koski, P., Virtanen, E., Vihlman, K. \& Valkonen, J.P.T. 2004. Occurrence and survival of potato scab pathogens (Streptomyces species) on tuber lesions: quick diagnosis based on a PCR-based assay. Plant Pathol. 53: 280-287.

Lindström, M., Kiviniemi, K., Hinderink, K., Somervuo, P., Nevas, M., Auvinen, P., Carter, A., Mason, D., Peck, M.W. \& Korkeala, H. 2007. Genomic DNA microarray analysis of Nordic group I (proteolytic) Clostridium botulinum type B strains reveals two clusters with distinct resistance to arsenic and cadmium. (Submitted).

Lindström, M. \& Korkeala, H. 2006. Laboratory diagnostics of botulism. Clinical Microbiol. Rev. 19: 298314. 
Mattinen, L., Tshuikina, M., Mäe, A. \& Pirhonen, M. 2004. Identification and characterization of Nip, necrosis-inducing virulence protein of Erwinia carotovora subsp. carotovora. Mol. Plant-Microbe Interact. 17: 1366-1375.

O'Connell, D. 2007. Bacterial physiology: Stuck on you... Nature Rev. Microbiol. 5: 571.

Rouillard, J.-M., Zuker, M. \& Gulari, E. 2003. OligoArray 2.0: design of oligonucleotide probes for DNA microarrays using a thermodynamic approach. Nucleic Acids Res. 31: 3057-3062.

Sebaihia, M. (ja 33 muuta auktoria) 2007. Genome sequence of a proteolytic (Group I) Clostridium botulinum strain Hall A and comparative analysis of the clostridial genomes. Genome Res. 17: 1082-1092.

Van der Wolf, J.M. \& De Boer, S.H. 2007. Bacterial pathogens of potato. In: Potato Biology and Biotechnology. D. Vreugdenhil, J. Bradshaw, C. Gebhardt, F. Govers, D.K.L. MacKerron, M.A. Taylor, and H.A. Ross, eds), pp. 619-641. Amsterdam: Elsevier. 